\title{
MJN \\ GLASGOW COMA SCALE, AGE AND SYSTOLIC BLOOD PRESSURE (GAP) AS IMPAIRMENT PREDICTOR OF HEAD INJURY PATIENTS
}

\author{
Tengku Isni Yuli Lestari Putri*, Ahsan, Dhelya Widasmara \\ Faculty of Medicine, University of Brawijaya, Indonesia \\ *Corresponding Author 's Email: tengkuisni15@gmail.com
}

\begin{abstract}
Background: Pathological conditions that occur in the brain as the result of brain tissue damage may cause changes in brain function. The severity level of brain tissue damage being the description of head injury. Therefore, this requires initial assessment to predict the impairment of head injury patients by using GAP. Purpose: This study aims to understand the accuracy of GAP in predicting impairment head injury patients. Method: This study used analytical observational design with retrospective approach. Total respondents in this study were 245 patients with medical records of head injury. Measurements were conducted by using observation sheet. Data were analyzed using Receiver Operating Characteristic (ROC). Results: The results showed that AUC values of GAP were 0.806 which explained that GAP had good value of discrimination against impairment of head injury patients. Conclusion: GAP could predict the outcome of head injury patients.
\end{abstract}

Keywords: Head Injury, GAP, Impairment

\section{INTRODUCTION}

Head injury is pathological condition that occurs in the brain as the result of brain tissue damage and cause changes in brain function (Urden, Stacy \& Lough, 2014; Walker et al., 2014). The severity level of brain tissue damage being the description of head injury that occurred (Kochanek \& Clark, 2016).

Head injury is becoming one of major problems in the world. Noble (2010) stated that the occurrence of head injury reached up to 1.4 million people annually with fatality rate reaching 30 in the first 72 hours (Noble, 2010). Valente \& Fisher (2011) reported the occurrence of head injury in United States being 7 million per year with fatality rate of $22-25 / 100,000$ people, or about 52,000 adults who died, 275,000 people are in intensive care in hospital and 1,365 did not receive intensive care in hospitals (out of the ER). Center for Disease Control and Prevention also stated that the occurrence of death from head injury in United States reached 138 people per day in which the leading causes of death are due to traffic accidents (CDC, 2015).

In Indonesia, the occurrence of head injury is related with high traffic accident. CBS in 2017 conducted survey related to the incidence of traffic accidents in 2017 that reached 98,419 people and $26 \%$ of death and the victims who suffered severe injuries reached 16\% (BPS, 2017). The high traffic accident led to cases of high trauma such as head injury. The number of cases of head injury that occurred were about $47.4 \%$ of the total of 95,906 traffic accident scene with a high fatality rate (Djaja et al., 2016).

The high head injury has high fatality rate, where the greater the damage, it will increase the risk of impairment and death in patients with head injury (Salama, Maray \& Hamed, 2015). Therefore, fast management is required with accurate and quality care by medical staff in 
overcoming the condition of head injury. The management along with the provision of fast, accurate and quality care depends heavily on the initial assessment carried out by medical staff (Damkliang et al., 2014; Wells \& Hutchinson, 2018). The good or accurate initial assessment can help to predict patient outcome in the future. Thus, it can guide medical staff to provide further management. The initial assessment that can be used to predict patient outcomes is the use trauma scoring (Rapsang \& Shyam, 2015).

Trauma scoring is a tool that is used for a preliminary assessment in predicting the outcome of patients in the future. One of trauma scoring that can be used to predict the patient's condition is GAP (Glasgow Coma Scale, Age and Systolic Blood Pressure). GAP is a scoring system that uses the body's physiological components in predicting patient outcome (Kondo et al., 2011). GAP is a modification of the MGAP (Mechanism, Glasgow coma scale, Age, and Arterial Pressure). But its mechanism could not predict well the patient's condition because it provides higher valuation on the mechanism of injury compared with blunt injury mechanism (Kondo et al., 2011; Sartorius et al., 2010). GAP consisted of three components, they are GCS (Glasgow Coma Scale), age and systolic blood pressure (Kondo et al., 2011). GAP has become a trauma scoring that can be used to predict the patient's death. Research conducted by Hasler et al., (2014) stated that GAP predicted mortality of trauma patients compared with MGAP (Hasler et al., 2014). This research was also supported by Kondo et al. (2011) which stated that the GAP is better in predicting mortality of trauma in patients compared with RTS, T-RTS and MGAP (Kondo et al., 2011).

Preliminary studies carried out by researcher in General Hospital of Dr. Slamet Martodirdjo, showed increase occurrence of head injury during 2017-2018. In 2017 head injury patients reached 281 people and in 2018 the head injury patients reached 352 people. This explained there was $25 \%$ increment in the number of head injury patients among these years. The major cause of head injury is traffic accident. Interviews conducted on nurses stated that they have not implemented the scoring trauma to predict the patient's condition. Based on the above background, the researchers were interested to use GAP in predicting impairment of head injury patients.

\section{METHODOLOGY}

This study used analytical observational design with retrospective approach. Total respondents in this study was 245 taken from medical records of head injury patients through purposive sampling method in General Hospital of Dr. Slamet Martodirdjo Pamekasan from $19^{\text {th }}$ February 2019 to $5^{\text {th }}$ March 2019 . The inclusion criteria in this study were based on the availability of complete medical record data on head injury patients including glasgow coma scale (GCS), age, systolic blood pressure and respiration rate and the medical record data of patients who suffered head injuries. The respondents were aged between 18-65 years. The exclusion criteria depended on the type of medical record available regarding head injury patients transferred to other hospitals, medical record data of head injury patients who leave the IGD on their own request, medical record of head injury of patients under the influence of alcohol and medical record data of head injury patients who have serious burns. The research instrument used was observation sheet. GAP assessment using comparative method of ROC in determining AUC, the cut-off point, the sensitivity and specificity of GAP.

\section{RESULTS}

Univariate

Table 1: Characteristics of Respondents based on GAP scores, age, systolic blood pressure, GCS and Respiration

\begin{tabular}{|l|c|c|c|c|c|}
\hline \multicolumn{1}{|c|}{ Variables } & N & Mean & Median & Min-Max & SD \\
\hline GAP scores & 245 & $18: 58$ & 19 & $14-24$ & 2.492 \\
\hline Age & 245 & 49.29 & 47 & $25-65$ & 12.73 \\
\hline $\begin{array}{l}\text { Systolic } \\
\text { blood } \\
\text { pressure }\end{array}$ & 245 & 97.68 & 95 & $68-134$ & 21744 \\
\hline GCS & 245 & $12: 31$ & 13 & $7-15$ & 2.636 \\
\hline Respiration & 245 & $22: 04$ & 20 & $7-36$ & $8: 26$ \\
\hline
\end{tabular}

Based on Table 1 it could be seen that the highest GAP score was 24 and the lowest GAP score was value was 14 , with mean value of 18:58. The oldest respondent was aged 65 years old and the youngest was 25 years old with mean value of 49.29 years old.

The maximum systolic blood pressure patient was 
$134 \mathrm{mmHg}$ and the minimum were $68 \mathrm{mmHg}$ with mean value of $97.68 \mathrm{mmHg}$. The maximum GCS score of patients was 15 and the minimum was 7 with mean value of 12:31. The maximum respiration rate patient was $36 \mathrm{x} / \mathrm{min}$ and the minimum were $7 \mathrm{x} / \mathrm{min}$ with mean value of $22.04 \mathrm{x} / \mathrm{min}$.

Table 2: Characteristics of Respondents based on impairment, GAP Category, Gender, Head Injury, and Head Injury Mechanism

\begin{tabular}{|c|l|c|c|}
\hline Variables & \multicolumn{1}{|c|}{ Category } & F & $\%$ \\
\hline Impairment & No impairment & 160 & 65.3 \\
& Impairment & 85 & 34.7 \\
\hline \multirow{2}{*}{ GAP Category } & High risk (<19) & 104 & 42.4 \\
& Low risk $(\geq 19)$ & 141 & 57.6 \\
\hline Gender & Male & 190 & 77.6 \\
& Female & 55 & 22.4 \\
\hline Head injury & Mild head injury & 138 & 56.3 \\
& Moderate head injury & 81 & 33.1 \\
& Severe head injury & 26 & 10.6 \\
\hline Mechanism of & Falling down & 73 & 29.8 \\
injury & Traffic accident & 172 & 70.2 \\
\hline
\end{tabular}

Table 2 showed that the majority respondents did not experience impairment among total respondents of 160 people $(65.3 \%)$. The most dominant GAP category showed that there was low risk $(\geq 19)$ with total of 141 respondents $(57.6 \%)$. The most dominant respondents' gender was male with total of 190 respondents $(77.6 \%)$. The category of head injury dominated by mild head injuries with total of 138 respondents $(56.3 \%)$. The most dominant cause of head injury occurred due to traffic accidents with total of 172 respondents $(70.2 \%)$.

\section{ROCAnalysis}

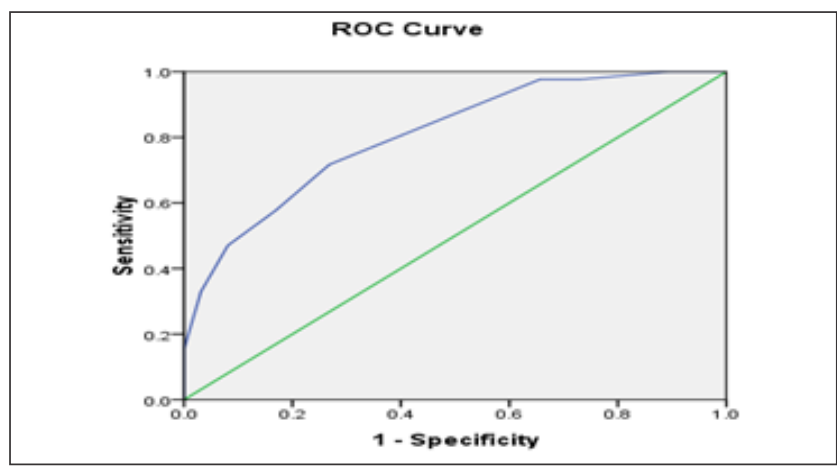

Source: Primary Data (2019)

Figure 1: ROC curve of GAP
Figure 1 illustrated the ROC curve of GAP as impairment predictor of head injury. Based on the curve, AUC obtained was above the midpoint of the curve. The ROC curve of GAP was described in Table 3 below.

Table 3: Description of Area Under Curve (AUC) Value of $\mathrm{GAP}$

\begin{tabular}{|l|c|c|c|c|c|}
\hline & \multirow{2}{*}{ AUC } & Std. & $\boldsymbol{p}$-value & \multicolumn{2}{|c|}{ CI 95\% } \\
\cline { 5 - 6 } & & Error & & LB & UB \\
\hline GAP Score & 0806 & 0028 & 0000 & 0751 & 0862 \\
\hline
\end{tabular}

Table 3 showed that the GAP had a value of $p=0.000$ which explained that GAP could be a strong predictor related to impairment in patients with head injury.

Table 4: Cut off Point, Sensitivity and Specificity of GAP

\begin{tabular}{|l|c|c|c|}
\hline & Cut off Point & Sensitivity & Specificity \\
\hline GAP score & 18.5 & 0.72 & 0.73 \\
\hline
\end{tabular}

Source: Primary Data (2019)

Based on Table 4 obtained cut off point value of GAP scores was 18.5 with a sensitivity of 0.72 and specificity of 0.73 . The sensitivity of 0.72 indicated clinically GAP may generate positive value depicting the impairment of head injury with percentage of $72 \%$. Specificity value of 0.73 indicated clinically GAP ability in producing negative value or no impairment of head injury with percentage of $73 \%$.

\section{DISCUSSION}

The results of this study indicated that GAP was good predictor of impairment of head injury patients in the ER of General Hospital of Dr. Slamet Martodirdjo Pamekasan with AUC values of GAP being 0.806 . These results indicated the cutoff point was at value of 18.5 with 0.72 sensitivity values that described the positive value or the impairment of head injury with percentage of $72 \%$ and specificity of 0.73 which explained the negative value or absence of impairment of head injury with percentage of $73 \%$. GAP cut points was divided into two categories: $<19$ (high risk) and $\geq 19$ (low risk). GAP that had value of $<19$ experiencing impairment compared to GAP that had value of $\geq 19$.

Respondents in this study who experience 
impairment could be detected through the change in GCS, systolic blood pressure and age of the patient. The third component was component of GAP. Patients who experienced impairment showed a GCS score of 8 which explained many respondents who experience impairment with severe head injury. Impairment of patients was characterized by a decrease in systolic blood pressure where the systolic blood pressure was $<90 \mathrm{mmHg}$ showing impairment of head injury, other than that of respondents who experienced impairment dominant at the age of $>40$ years.

The result was consistent with research conducted by Roy et al., (2016) and Ahun et al., (2014) which stated that the GAP could predict outcomes such as exacerbations and mortality in trauma patients with head injury. GAP scored physiological trauma system introduced by Kondo et al., in 2011 based on modified score MGAP (Mechanism, Glasgow Coma Scale, Age and Systolic Blood Pressure) developed by Sartorius et al., in 2010 .

MGAP is the best and latest scoring systems for predicting in-hospital mortality for trauma patients. However, its procedure is doubtful because it gives higher scores for penetrating trauma, which is not always more severe than blunt trauma. Moreover, the mechanism score based on penetrating trauma generally affects fewer than $10 \%$ of all of trauma patients. Since MGAP being slightly difficult to use in the clinical setting, the MGAP was modified to new Glasgow Coma Scale, Age, and Systolic Blood Pressure (GAP) scoring system (Sartorius et al., 2010; Shoko et al., 2010).

GAP score consists of three components: GCS, age and systolic blood pressure. GCS is a physiological scoring system that was first introduced by Teasdale \& Jennet (1974), that was used to evaluate the level of consciousness of the patient, the patient's clinical status and became a benchmark tool in patients with head injury (Kung et al., 2011; Salim, 2015; Teasdale \& Jennett, 1974).

GCS could be used to measure the neurological disorder and it was generally used to describe the level of head injury. GCS had an important function in estimating the risk of impairment of the patient's death at the beginning of the injury. GCS should be carried out at the beginning of the examination in patients with head injury before getting paralytic drug therapy and intubation. Level of consciousness indicated the chances of life and healing in patients with head trauma. The lower score of GCS would increase the risk of impairment and death in such patients (Okasha, Fayed \& Saleh, 2014).

Research conducted by Lingsma et al., (2014) showed that head injury patients with initial GCS score of $>11$ showed good outcome within 24 hours with a percentage of $82 \%$ and poor outcome with the percentage of $18 \%$. This poor outcome could gradually be decreased if the initial GCS examination results were low. In patients with head injury with initial GCS score of 3-4 in the first 24 hours after the trauma of only $7 \%$ who had good outcome and in case of death as much as $87 \%$. Assessment outcome in head injury patients with GCS score $<8$ within 3-6 months also had poor outcome or had disability.

The age components in GAP is one impairment predictor until the death of patient. Age was one of component of GAP score that could predict impairment leading to mortality due to head injury among patient. Research conducted by Laytin et al., (2017) stated that among 540 people who experienced impairment till death were 18.746 people, found $25 \%$ of patients were above 40 years of age (Laytin et al., 2015).

According Dhandapani et al., (2012), age is a factor that affected the outcome of the patient both physiologically and psychologically. Head injury could occur at the age of $>40$ years and $<40$ years old. Patients who experienced severe head injury, had major longterm risks related to neurological problems. In patients with mild head injury with the age of $>40$ years would undergo functional impairment of the body in the first six months compared to patient with age of $<40$ years. Age effected outcome in patients with head injuries related to impaired neuro function as a result of an injury that would impair the patient's clinical condition. Moreover, at an older age, there was a decrease in bodily functions so that when an injury occurred, the body would experience a greater impact.

Another component of the GAP causing impairment and predictor death in patients with head injury was systolic blood pressure. Blood pressure was one of the parameters that could predict hemodynamic impairment and death in patients with head injury. Blood pressure was the pressure exerted by the blood 
against the wall of the blood vessel depending on the volume of blood in the blood vessels and distensibility of the blood vessel wall. Blood pressure consisted of systolic and diastolic blood pressure. Systolic blood pressure was the maximum pressure generated by the arteries when blood flows into the blood vessels with average value of $120 \mathrm{mmHg}$. Diastolic blood pressure was a minimal pressure in the arteries when blood flows out into smaller vessels with an average value of 80 mmHg (Sherwood, 2016).

Systolic blood pressure $<90 \mathrm{mmHg}$ was related to impairment rate and death after 90 days of trauma and obtaining longer ICU treatment. Systolic blood pressure should be maintained between $90-110 \mathrm{mmHg}$ so that the auto regulation function remains normal. This auto regulation function was important to prevent secondary head trauma, especially ischemic neuronal damage (Irawan et al., 2010). Based on the above, it could be concluded that GAP with GCS components, age and systolic blood pressure could predict impairment of head injury patients.

\section{CONCLUSION}

GAP could predict impairment of head injury patients. GAP with three components assessment (GCS components, age and systolic blood pressure) could make it easier for the medical staff in hospitals to carry out initial assessments of patients at risk of impairment. For further research should is necessary with more samples for the development of more prospective methods.

\section{REFERENCES}

Ahun, E., Koksal, O., Sigirli, D., Torun, G., Donmez, S.S. \& Armagan, E. (2014). Value of the Glasgow coma scale, age, and arterial blood pressure score for predicting the mortality of major trauma patients presenting to the emergency department. Ulus Travma Acil Cerrahi Derg, 20(4), pp 241-247.

Badan Pusat Statistik (BPS) (2017). How Many Traffic Accidents in Indonesia? Jakarta: Badan Pusat Statistik. Retrieved from: https:/databoks.katadata.co.id/datapublish/2017/05/24/berapa-jumlah-kecelakaan-lalulintas-di-indonesia

Centre of Disease Control Prevention (CDC) (2015). Rates of TBI-related Emergency Departement Visits, Hospitalizations and Deaths. USA: Center for Disease Control and Prevention. Retrieved from: https://www.cdc.gov/traumaticbraininjury/data/rates.html

Damkliang, J., Considine, J., Kent, B. \& Street, M. (2014). Initial emergency nursing management of patients with severe traumatic brain injury: Development of an evidence-based care bundle for the Thai emergency department context. Australasian Emergency Nursing Journal, 17(4), pp 152-160.

Dhandapani, S., Manju, D., Sharma, B. \& Mahapatra, A. (2012). Prognostic significance of age in traumatic brain injury. Journal of Neurosciences in Rural Practice, 3(2), pp 131-135.

Djaja, S., Widyastuti, R., Tobing, K., Lasut, D. \& Irianto, J. (2016). Gambaran Kecelakaan Lalu Lintas Di Indonesia Tahun 2010-2014. Jurnal Ekologi Kesehatan, 15(1), pp 30-42.

Hasler, R.M., Mealing, N., Rothen, H.U., Coslovsky, M., Lecky, F. \& Juni, P. (2014). Validation and reclassification of MGAP and GAP in hospital settings using data from the Trauma Audit and Research Network. Journal of Trauma and Acute Care Surgery, 77(5), pp 757-763.

Irawan, H., Setiawan, F., Dewi, D. \& Dewanto, G. (2010). Comparison of Glasgow Coma Scale and Revised Trauma Score to Predict Disability of Head Trauma Patient in Atma Jaya Hospital. Journal of the Indonesian Medical Association, 60(10), pp 437-442.

Kochanek, P.M. \& Clark, R.S.B. (2016). Traumatic brain injury research highlights in 2015. The Lancet Neurology, 15(1), pp 13-15. 
Kondo, Y., Abe, T., Kohshi, K., Tokuda, Y., Cook, E.F. \& Kukita, I. (2011). Revised trauma scoring system to predict in-hospital mortality in the emergency department: Glasgow Coma Scale, Age, and Systolic Blood Pressure score. Critical Care, 15(4), pp 1-8.

Kung, W.-M., Tsai, S.-H., Chiu, W.-T., Hung, K.-S., Wang, S.-P., Lin, J.-W. \& Lin, M.-S. (2011). Correlation between Glasgow coma score components and survival in patients with traumatic brain injury. Injury, 42(9), pp 940-944.

Laytin, A.D., Kumar, V., Juillard, C.J., Sarang, B., Lashoher, A., Roy, N. \& Dicker, R.A. (2015). Choice of injury scoring system in low- and middle-income countries: Lessons from Mumbai. Injury, 46(12), pp 2491-2497.

Lingsma, H.F., Yue, J.K., Maas, A.I., Steyerberg, E.W., Manley, G.T. \& Investigators, T.-T. (2015). Outcome prediction after mild and complicated mild traumatic brain injury: external validation of existing models and identification of new predictors using the TRACK-TBI pilot study. Journal of Neurotrauma, 32(2), pp 83-94.

Noble, K.A. (2010). Traumatic Brain Injury and Increased Intracranial Pressure. Journal of Peri Anesthesia Nursing, 25(4), pp 242-250.

Okasha, A.S., Fayed, A.M. \& Saleh, A.S. (2014). The FOUR score predicts mortality, endotracheal intubation and ICU length of stay after traumatic brain injury. Neurocritical Care, 21(3), pp 496-504.

Rapsang, A.G. \& Shyam, D.C. (2015). Scoring systems of severity in patients with multiple trauma. Cirugía Española, 93(4), pp 213-221.

Roy, N., Gerdin, M., Schneider, E., Kizhakke Veetil, D.K., Khajanchi, M., Kumar, V., Saha, M.L., Dharap, S., Gupta, A., Tomson, G. \& von Schreeb, J. (2016). Validation of international trauma scoring systems in urban trauma centres in India. Injury, 47(11), pp 2459-2464.

Salama, D.I., Maray, A.G. \& Hamed, W. (2015). Identification of clinical and radiological predictors of outcome in head trauma patients in the emergency departement. Biolife, 3(3), pp 644-652.

Salim, C. (2015). Sistem Penilaian Trauma. CDK, 42(9), pp 702-709.

Sartorius, D., Le Manach, Y., David, J. S., Rancurel, E., Smail, N., Thicoipe, M., Wiel, E., Ricard-Hibon, A., Berthier, F., Gueugniaud, P.Y. \& Riou, B. (2010). Mechanism, glasgow coma scale, age, and arterial pressure (MGAP): a new simple prehospital triage score to predict mortality in trauma patients. Critical Care Medicine, 38(3), pp 831-837.

Sherwood, L. (2016). Fisiologi Manusia Dari Sistem ke Sistem. Edisi 8, EGC: Jakarta.

Shoko, T., Shiraishi, A., Kaji, M. \& Otomo, Y. (2010). Effect of pre-existing medical conditions on in-hospital mortality: analysis of 20,257 trauma patients in Japan. Journal of the American College of Surgeons, 211(3), pp 338-346.

Teasdale, G. \& Jennett, B. (1974). Assessment of coma and impaired consciousness. A practical scale. Lancet, 2(7872), pp 81-84.

Urden, L.D., Stacy, K.M. \& Lough, M.E. (2014). Critical Care Nursing: Diagnosis and Management Seventh Edition. Mosby: St Louis.

Valente, S.M. \& Fisher, D. (2011). Traumatic Brain Injury. The Journal for Nurse Practitioners, 7(10), pp 863-870.

Walker, B.R., Colledge, N.R., Ralston, S. H. \& Penman, I.D. (2014). Davidson's Principle \& Practice of Medicine $22^{\text {nd }}$ Edition. Elsevier: British.

Wells, A.J. \& Hutchinson, P.J.A. (2018). The management of traumatic brain injury. Surgery (Oxford), 36(11), pp 613-620. 